\title{
Non-Oil Exports in the Economic Growth of Nigeria: A Study of Agricultural and Mineral Resources
}

\author{
Adesoji Adetunji Adenugba \\ Crawford University \\ Faith - City, Igbesa, Ogun State \\ adesojiadenugba@gmail.com
}

Sotubo Oluwatimilehin Dipo

Crawford University

Faith - City, Igbesa, Ogun State

timdipo@yahoo.co.uk

Doi:10.5901/jesr.2013.v3n2p403

\begin{abstract}
Exports have been described as catalysts for overall development and increase the earnings of the country thereby creating an avenue for growth by raising the national income of the country. Since the importance of foreign income cannot be over-emphasized, this study therefore examines the performance of non - oil exports over the years as well as the reason for that pattern and level of performance. The study evaluates the performance of Nigeria's export promotion strategies as to whether they have been effective in diversifying the productive base of the Nigerian Economy from Crude oil as the major source of foreign exchange. The study runs from 1981 through 2010. Findings from the study reveal that non - oil exports have performed below expectations giving reason to doubt the effectiveness of the export promotion strategies that have been adopted in the Nigerian Economy. The study reveals that the Nigerian Economy is still far from diversifying from crude oil export and as such the crude oil sub - sector continues to be the single most important sector of the economy. The study made some recommendations for diversification to be achieved and for enhancing the productivity and output of non -oil commodities as well as providing markets for the commodities.
\end{abstract}

Keywords: Exports, diversification, Nigerian Economy, crude oil, non-oil commodities, economic development

\section{Introduction}

Exportation is required by any economy to enhance revenue and usher in economic growth and development. It is therefore crucial for economic progress and this has informed the idea of export-led growth. Export is a catalyst necessary for the overall development of an economy (Abou-Strait, 2005). It was also noted that foreign trade creates an avenue for foreign capital to flow into a country (Ricardo, 1817). This increases the earnings of the country thereby creating an avenue for growth by raising the national income of the country. It also increases the level of employment in the economy as a higher demand for exports will require more production which will in turn lead to the employment of more people. Exportation by a country also helps attain a favourable balance of trade and balance of payment position for the exporting country provided its exports reasonably exceed it's imports.

In a country like Nigeria where the level of investment is low, foreign capital is very much needed in order to accelerate the creeping rate of economic growth. The Nigerian economy is one that depends largely on foreign trade for growth and is also one which depends majorly on one export commodity at a time. For instance, at independence, the major export commodity was cocoa and the leading sector in the economy was the agricultural sector but today, the major export commodity is crude oil and the leading sector is now the petroleum sector. This has not allowed for balanced growth in the economy as some sectors have been allowed to grow while growth has been impeded in others and this has made the country remain a developing country. 
In Nigeria, crude oil is the major export because of the large revenue it generates. This has led the economy to focus on the petroleum sector while ignoring the other sectors as well as the potential revenue they can generate. This research aims to determine if non-oil exports contribute significantly to the Gross Domestic Product (GDP) of the economy and to what extent they contribute. It also aims to determine the factors responsible for the current performance of the non-oil sector.

\section{Statement of the Problem}

Nigeria is yet to attain the ranks of a developed economy due to lack of structural change, among other factors. Also, it was observed that a factor crucial to this lack of economic progress is the lack of economic diversity which has caused the economy to rely heavily on crude oil for revenues and as the major export commodity in the economy (Osuntogun et al, 1997). Prior to the 1970s, Nigeria's exports were predominantly non-oil commodities with agricultural commodities accounting for the lion share. However, in the 1970s, when the price of crude oil in the international market sky rocketed, the share of non-oil exports began falling and have remained low ever since. This is majorly due to the money-spinning nature of oil exports which makes it more profitable to export oil and less profitable to export non-oil commodities. This has cause a rather heavy dependence on the oil sector and the proceeds from the exportation of crude oil. This heavy reliance subjects the country to difficulties when the price of crude oil, the major export commodity, is low in the international market. In light of this, the government adopted various strategies to boost non-oil exports and stabilize the economy. In spite of these efforts, the performance and contribution of the non-oil exports sector has remained very low. The sector has continued to perform below its full potential. This research is therefore carried out to determine to what extent the diversification of the economy will help enhance the economic progress of the economy, to appraise the past efforts at diversification and to discover how the current performance of the non-oil sectors can be improved.

\section{Brief literature review}

\subsection{Exportation as a tool for economic growth}

Exports play a vital role in the growth of any economy just as Ricardo (1817) pointed out that foreign trade is highly beneficial to a nation. Also, as observed by Singh (2010), trade is one of the several catalysts of productivity and growth and hence its contribution is contingent on its weight in the aggregate economic activity. The knowledge of this has helped many nations achieve economic growth and development. In light of this, the Nigerian economy left import substitution policies for the export promotion strategies or export-led growth approach.

Export promotion strategies or outward oriented strategies are policies that encourage exports, often through the free movement of capital, workers, enterprises, and students; a welcome to multinational corporations; and open communications (Todaro \& Smith, 2011). According to Abou-Strait (2005), an export led growth strategy aims to provide producers with incentives to export their goods through various economic and governmental policies. These strategies are aimed at increasing the level of national output in order to increase the volume of exports of the nation. The government encourages and helps to enhance the output of domestic industries for it to exceed the domestic demand so that the surplus can be sold in the international market for an inflow of foreign exchange.

Export promotion involves encouraging domestic production for exportation usually by providing incentives for the domestic producers. This could be in the form of tax cuts or holidays, subsidies, finding markets for such products, providing special loans, etc. It is however important to note that this export promotion strategy rests upon diversification and expansion of non-traditional exports (Dunn Jr. \& Mutti, 2004). As early as the 1970s, studies were published showing that developing countries that pursued an export-led approach experienced far more rapid economic growth than did countries with protectionist policies. The original Four Tigers (Hong Kong, Taiwan, Singapore, and South Korea) were the subject of most of this early research, but the second wave of Asian newly industrialized countries or NICs (Indonesia, Thailand, Malaysia, and 
China) has also been very successful in pursuing export markets. As a result, these countries have grown rapidly. India, Mexico, and Brazil could be added as recent converts to this approach (Dunn \& Mutti, 2004).

Abou-Strait (2005) found out that exports of goods and services represent one of the most important sources of foreign exchange income that ease the pressure on the balance of payments and create employment opportunities.

Also, according to Frankel \& Romer (1999), trade increase GDP which ultimately increases the income per person. In other words, trade not only enhances economic growth but is also a useful tool in achieving economic development provided there are other structural and institutional changes in the economy and as Morton and Tullock (1976) noted, international trade brings gains to a nation and it acts as a stimulus to growth.

\subsection{Rationale for export diversification}

Export trade is an instrument for growth. It increases foreign exchange earnings, improves balance of payment position, creates employment and development of export oriented industries in the manufacturing sector and improves government revenue through taxes, levies and tariffs. These benefits will in turn enhance the process of growth and development in such economy. However, before these benefits can be fully realized, the structure and direction of these exports must be carefully tailored such that the economy will not depend on only one sector for the supply of needed foreign exchange (Onayemi \& Akintoye, 2009). Hence, there is a need for economic diversification in the economy.

Abebefe (1995) noted that Nigeria's over-dependence on crude oil is dangerous for two reasons one being because crude oil is a wasting asset with a proven reserve which would eventually become depleted and secondly, the vagaries of the oil market has resulted in a significant decline in the earnings because of the exogeneously determined price of crude oil.

Osuntokun and Edordu (2001), in their research on the potentials for diversifying Nigeria's non-oil export to non-traditional markets found out that Nigeria could not fully utilize its potential because the implementation of export promotion policies followed key market concentration strategy i.e. concentration on developed countries like Europe or USA, thereby resulting in less attention to gathering trade facilitating information that may further diversify Nigeria's export market to less developes countries such as the countries in sub-saharan Africe. This inter-regional trade, if conducted, will require lower transportation costs and enhance the competetiveness of commodities traded and ensure market clearing of export commodities thereby reducing such problems faced by exports to developed countries.

Lyakurwa (1991) also posited that export diversification is important because it will play an important role in reducing the variability of the export earnings of developing countries and raising the growth rates of both exports and domestic output. However, he warned that the composition of a diversifying country's exports has to match the import structure of the target countries (Osuntogun, Edordu, \& Oramah, 1997).

According to the World Trade Organisation (2010), diversification of countries export base increases local production, employment, income and economic growth. Developing countries that export large amounts of a small number of products have export revenues that are quite volatile. Many OPEC members derive more than 80 percent of their export revenues from oil and gas. As a result, the decline in oil prices from the early 1980 s to 2000 reduced export receipts. After the four Asian Tigers (South Korea, Singapore, Taiwan and Hong Kong) achieved economic progress through export promotion, Dunn and Mutti (2004) observed that the export promotion strategy does enhance economic growth but they also pointed out that the strategy rests upon the diversification and expansion of non-traditional exports.

Osuntogun, Edordu, and Oramah (1997) discovered that the core of the export-led strategy is the diversification of export products and export markets to minimize risks and ensure a more stable and sustainable current account position. Lewis (1980) also found that diversification of exports will help countries achieve and maintain a high level of economic growth.

Opara (2010) said that exports are the bed-rock of any economic development which is meaningfully centred on non-oil export in most countries of the world. He also said that promoting non-oil export products will bring about a reduction of the nation's level of dependence on crude oil or what he describes as, "monocultural foreign trade product". Opara (2010) listed some benefits that the diversification from oil to non-oil exports will have on the Nigerian economy as stated by the Nigerian Export Promotion Council. The benefits include: 
- The export of non-oil products increase the foreign exchange earnings of the country, which assist in the financing of other economic sectors of the nation.

- Export of non-oil products create employment and reduce unemployment problems in the country.

- The living standard of the people in the exporting country will improve or be better.

- The export of non-oil products may bring about increase in sales and profits to firms that export their products.

- Foreign trade may also improve the product quality and achieve a reduction in production cost, which may be brought about by mass production for export.

- Business expansion is another benefit that may also result from export marketing.

- Recognition and Reputation of firms may also be enhanced when quality, quantity, and reliability of the firm are considerably improved as the firm successfully engages in export marketing.

He concluded by adding that the benefits that may accrue to Nigerian firms that engage in non-oil export are by extension beneficial to the country where the exporting products are consumed, and will have positive "spread effect" on both countries' economies and the well-being of the citizens.

\subsection{Government strategies to promote non-oil exports}

As early as the 1970s, the government saw the need to diversify its export base and therefore established various agencies and put various policies in place to improve the economic situation in the country by increasing the share of non-oil products in total exports. In this section, we will examine some of these policies.

\subsection{The nigerian export promotion council}

The Nigerian Export Promotion Council (NEPC) was established in 1976. According to Abebefe (1995), its mandates are to:

- Spearhead national effort in export development and promotion by generating ideas, suggestions and measures designed to advance the course of Nigeria's export trade.

- Advise and assist the government in the identification of export oriented industries and to help stimulate the growth of non-traditional exports from Nigeria.

- Assist the government in the creation of the necessary infrastructures such as export incentives and trade information services.

3.6 The export incentives and miscellaneous provisions decree no. 18 of 1986.

This decree was promulgated on the $11^{\text {th }}$ of July,1986 and it led to the extablishment of institutions and programmes all geared towards the promotion of exports, particularly non-oil exports.. The decree provided for the establishment of three funds; Export Development. Fund, Export Expansion Grant Fund and Export Adjustment Scheme Fund (CBN, 2010).

\subsection{The nigerian export-import (NEXIM) bank}

NEXIM was established in 1991 as an export credit agency with the broad objective of attaining overall export growth as well as structural balance and diversifying the composition and destination of Nigerian Exports. The bank provides 3 main services which are; credit, risk-bearing and trade information and export advisory services.

\subsection{Export processing zones}

This was established by the decree no. 34 of 1991. An Export Processing Zone (EPZ) is a special enclave outside a nation's normal custom barriers where foreign and domestic firms may manufacture or assemble goods for export without being subjected to the normal customs duties on imported raw materials and finished products present in that economy; firms operating within the zone are normally exempted from industrial regulation 
applying within the domestic economy, especially with regards to foreign ownership of firms, repatriation of profits, employments of nationals, access of foreign exchange, etc (Afeikhana, 1996).

\subsection{Appraisal of government strategies}

The various institutions and policies that have been adopted by the government to boost non-oil exports have produced results. However, these results have been less than satisfactory. Ogunkola et al (2006) observed the proportion of oil to total exports and concluded that since crude oil accounted for over 90.0 percent of total export therefore all efforts directed at diversifying export from oil to non-oil products are yet to materialize.

\section{Theoretical Positions}

\subsection{Theory of absolute advantage}

This theory was propounded by Adam Smith in his 1776 publication, An Inquiry into the Nature and Causes of the Wealth of Nations. This theory uses a two by two by two model, i.e. there are two countries involved in the trading of two commodities and using only two factors of production; labour and capital. The theory says that a country should export products in which it is more productive than other countries: that is, goods for which it can produce more output per unit of input than others can (i.e. in which it has an absolute advantage) while importing those goods where it is less productive than other countries (i.e. in which it has an absolute disadvantage) (Dunn Jr. \& Mutti, 2004).

Absolute advantage means the ability of a country to produce a larger quantity of a good with the same amount of resources as another country. The country's absolute advantage may be due to the nature of its resources or to its production skills (Hoag \& Hoag, 2006).According to Smith, each nation benefits by specializing in the production of the good that it produces at a lower cost than the other nation, while importing the good that it produces at a higher cost. This will increase specialization, world output and the gains from trade (Carbaugh, 2004).

According to this theory, foreign trade is a positive-sum game, because both countries involved will benefit from the trade. Thus, a nation need not gain at the expense of other nations, as all nations could gain simultaneously (Sylvester \& Aiyelabola, 2012).

However, there arises the question of whether or not to trade when one of the two countries trading has an absolute advantage in the production of the two commodities. Should trade still take place when one partner can produce both commodities more efficiently than the other partner? The theory failed to answer this question satisfactorily and that gave rise to Ricardo's theory of Comparative Advantage.

\subsection{Theory of comparative advantage}

This theory was put forward by David Ricardo in 1817 because he was dissatisfied with the looseness in Smith's theory (Carbaugh, 2004).

According to Ricardo's theory of comparative advantage, even if a nation has an absolute cost disadvantage in the production of both goods, there still exists a basis for mutually beneficial trade. The less efficient nation should specialize in the production and exportation of the good in which it is relatively less inefficient (where its absolute disadvantage is least) while the more efficient nation should specialize in the production and exportation of the good in which it is relatively more efficient (where its absolute advantage is greatest).

This theory proved to be better than Smith's absolute advantage theory because it is possible for a nation not to have an absolute advantage in anything but it is not possible for one nation to have a comparative advantage in everything and the other nation to have a comparative advantage in nothing. That is because comparative advantage depends on relative costs (Carbaugh, 2004). 


\section{Statement of hypothesis}

The hypothesis for this research work is:

$\mathrm{H}_{\mathrm{o}}$ : Non-oil exports do not contribute significantly to Nigeria's Gross Domestic Product.

$\mathrm{H}_{1}$ : Non-oil exports contribute significantly to the nation's Gross Domestic Product (GDp)

\section{Methodology}

This research adopts a non-experimental research design. The data used were obtained from secondary sources and therefore, no sampling was done neither was any sampling technique used.

Data and the literature for this study were obtained from secondary sources. Frequent visits were made to the school as well as the CBN library to access the materials. The websites of such government agencies as the CBN and the Ministry of Trade and Investment were instrumental in the collection of statistical information used to carry out the least squares regression. Also, the websites of the Ministry of Agriculture and Rural Development, the Ministry of Solid Minerals Development, the CBN and the Nigerian Institute for SocioEconomic Research (NISER) were helpful in the compilation of the literature base. The internet database, EBSCOhost, was also very resourceful as it provided many academic journals that helped in the course of this research. The secondary sources also include textbooks, statistical bulletins, annual reports, academic journals, previous research works and other downloads from the internet database.

Descriptive and inferential statistic tools were used for analysis of the data gathered. Frequency distribution and simple percentages were used for the descriptive analysis and least squares (LS) regression was used for the inferential statistics. The hypothesis formulated was tested. The statistical application, EViews, will be used for the analysis.

\subsection{Model specification}

Based on earlier works done on the subject, a model was drawn up for the purpose of this study. The model will help to verify the impact of non-oil export earnings on the GDP of the nation for the period under consideration. According to the model and for the purpose of this study, the GDP of the nation depends on the receipts from non-oil commodity exports and the exchange rate.

The functional form of the model is:

$G D P=f(N O X, X R)$

The research model is set explicitly in double-logarithmic form, as follows :

LOGGDP $=\beta_{0}+\beta_{1}$ LOGNOX $+\beta_{2}$ LOGXR

Where:

GDP $=$ Gross Domestic Product

NOX $=$ Non-oil Exports

$X R=$ Exchange Rate

$\beta_{0}=$ Constant Intercept

$\beta_{1}=$ coefficient of Non-oil Exports

$\beta_{2}=$ coefficient of exchange rate

LOG = Logarithms

\section{Presentation, analysis and interpretation of data}

The data collected for the purpose of this study are shown below.

Table 1 - Composition and percentages of exports.

\begin{tabular}{|l|l|l|l|l|l|}
\hline Year & $\begin{array}{l}\text { Total exports } \\
(\mathrm{Am})\end{array}$ & $\begin{array}{l}\text { Oil exports } \\
(\mathrm{Am})\end{array}$ & $\begin{array}{l}\text { Oil as a percent of } \\
\text { total exports }(\%)\end{array}$ & $\begin{array}{l}\text { Non-oil exports } \\
(\mathrm{Am})\end{array}$ & $\begin{array}{l}\text { Non-oil as a percent } \\
\text { of total exports }(\%)\end{array}$ \\
\hline 1981 & $11,023.3$ & $10,680.5$ & 96.89 & 342.80 & 3.11 \\
\hline
\end{tabular}




\begin{tabular}{|l|l|l|l|l|l|}
\hline 1982 & $8,206.4$ & $8,003.2$ & 97.52 & 203.20 & 2.48 \\
\hline 1983 & $7,502.5$ & $7,201.2$ & 95.98 & 301.30 & 4.02 \\
\hline 1984 & $9,088.0$ & $8,840.6$ & 97.28 & 247.40 & 2.72 \\
\hline 1985 & $11,720.8$ & $11,223.7$ & 95.76 & 497.10 & 4.24 \\
\hline 1986 & $8,920.6$ & $8,368.5$ & 93.81 & 552.10 & 6.19 \\
\hline 1987 & $30,360.6$ & $28,208.6$ & 92.91 & 2152.00 & 7.09 \\
\hline 1988 & $31,192.8$ & $28,435.4$ & 91.16 & 2757.40 & 8.84 \\
\hline 1989 & $57,971.2$ & $55,016.8$ & 94.90 & 2954.40 & 5.10 \\
\hline 1990 & $109,886.1$ & $106,626.5$ & 97.03 & 3259.60 & 2.97 \\
\hline 1991 & $121,535.4$ & $116,858.1$ & 96.15 & 4677.30 & 3.85 \\
\hline 1992 & $205,611.7$ & $201,383.9$ & 97.94 & 4227.80 & 2.06 \\
\hline 1993 & $218,770.1$ & $213,778.8$ & 97.72 & 4991.30 & 2.28 \\
\hline 1994 & $206,059.2$ & $200,710.2$ & 97.40 & 5349.00 & 2.60 \\
\hline 1995 & $950,661.4$ & $927,565.3$ & 97.57 & 23096.10 & 2.43 \\
\hline 1996 & $1,309,543.4$ & $1,286,215.9$ & 98.22 & 23327.50 & 1.78 \\
\hline 1997 & $1,241,662.7$ & $1,212,499.4$ & 97.65 & 29163.30 & 2.35 \\
\hline 1998 & $751,856.7$ & $717,786.5$ & 95.47 & 34070.20 & 4.53 \\
\hline 1999 & $1,188,969.8$ & $1,169,476.9$ & 98.36 & 19492.90 & 1.64 \\
\hline 2000 & $1,945,723.3$ & $1,920,900.4$ & 98.72 & 24822.90 & 1.28 \\
\hline 2001 & $1,867,953.9$ & $1,839,945.3$ & 98.50 & 28008.60 & 1.50 \\
\hline 2002 & $1,744,177.7$ & $1,649,445.8$ & 94.57 & 94731.85 & 5.43 \\
\hline 2003 & $3,087,886.4$ & $2,993,110.0$ & 96.93 & 94776.44 & 3.07 \\
\hline 2004 & $4,602,781.5$ & $4,489,472.2$ & 97.54 & 113309.35 & 2.46 \\
\hline 2005 & $7,246,534.8$ & $7,140,578.9$ & 98.54 & 105955.88 & 1.46 \\
\hline 2006 & $7,324,680.6$ & $7,191,085.6$ & 98.18 & 133594.99 & 1.82 \\
\hline 2007 & $8,309,758.3$ & $8,110,500.4$ & 97.60 & 199257.94 & 2.40 \\
\hline 2008 & $10,161,490.1$ & $9,913,651.1$ & 97.56 & 247838.99 & 2.44 \\
\hline 2009 & $8,356,385.6$ & $8,067,233.0$ & 96.54 & 289152.57 & 3.46 \\
\hline 2010 & $11,035,794.5$ & $10,639,417.4$ & 96.41 & 396377.16 & 3.59 \\
\hline & & & & & \\
\hline
\end{tabular}

Source: CBN Statistical Bulletin 2010

From the table above, it is evident that the performance of the non-oil export sector has been dismally poor, reaching a minimum of $1.28 \%$ in 2000 and attaining a maximum of $8.84 \%$ in 1988 . The earnings during this period was very unstable. The sector contributed an average of $3.31 \%$ to the foreign exchange earnings during the period under review.

Table 2 - Contribution of Agricultural and Solid Mineral Resources to GDP and Percentage of Non-oil exports to total exports.

\begin{tabular}{|c|c|c|c|c|}
\hline Year & $\begin{array}{l}\text { \% of Agric to } \\
\text { GDP }\end{array}$ & $\begin{array}{l}\% \text { of Solid } \\
\text { Minerals to GDP }\end{array}$ & $\begin{array}{c}\text { Non-oil as a } \begin{array}{c}\text { Oil as a percent of } \\
\text { percent of total (\%) }\end{array} \\
\text { total exports (\%) }\end{array}$ \\
\hline 1981 & 28.26 & 1.08 & 3.11 & 96.89 \\
\hline 1982 & 29.77 & 1.12 & 2.48 & 97.52 \\
\hline 1983 & 31.79 & 0.92 & 4.02 & 95.98 \\
\hline 1984 & 30.46 & 0.80 & 2.72 & 97.28 \\
\hline 1985 & 32.70 & 0.45 & 4.24 & 95.76 \\
\hline 1986 & 35.02 & 0.24 & 6.19 & 93.81 \\
\hline 1987 & 33.99 & 0.26 & 7.09 & 92.91 \\
\hline 1988 & 34.91 & 0.27 & 8.84 & 94.16 \\
\hline 1989 & 34.16 & 0.27 & 5.10 & \\
\hline
\end{tabular}




\begin{tabular}{|l|l|l|l|l|}
\hline 1990 & 31.52 & 0.25 & 2.97 & 97.03 \\
\hline 1991 & 32.97 & 0.26 & 3.85 & 96.15 \\
\hline 1992 & 32.92 & 0.26 & 2.06 & 97.94 \\
\hline 1993 & 32.96 & 0.27 & 2.28 & 97.72 \\
\hline 1994 & 33.70 & 0.28 & 2.60 & 97.40 \\
\hline 1995 & 34.19 & 0.28 & 2.43 & 97.57 \\
\hline 1996 & 34.12 & 0.27 & 1.78 & 98.22 \\
\hline 1997 & 34.60 & 0.28 & 2.35 & 97.65 \\
\hline 1998 & 35.00 & 0.29 & 4.53 & 95.47 \\
\hline 1999 & 36.70 & 0.30 & 1.64 & 98.36 \\
\hline 2000 & 35.83 & 0.29 & 1.28 & 98.72 \\
\hline 2001 & 34.32 & 0.30 & 1.50 & 98.50 \\
\hline 2002 & 43.89 & 0.26 & 5.43 & 94.57 \\
\hline 2003 & 42.60 & 0.25 & 3.07 & 96.93 \\
\hline 2004 & 40.98 & 0.26 & 2.46 & 97.54 \\
\hline 2005 & 41.19 & 0.27 & 1.46 & 98.54 \\
\hline 2006 & 41.72 & 0.28 & 1.82 & 98.18 \\
\hline 2007 & 42.01 & 0.30 & 2.40 & 97.60 \\
\hline 2008 & 42.13 & 0.32 & 2.44 & 97.56 \\
\hline 2009 & 41.70 & 0.33 & 3.46 & 96.54 \\
\hline 2010 & 40.84 & 0.34 & 3.59 & 96.41 \\
\hline
\end{tabular}

Source: CBN Statistical Bulletin 2010

Graph 1 - Showing the percentage contribution of agric and mineral resources to GDP as well as the percent of Oil and Non-oil in total exports.

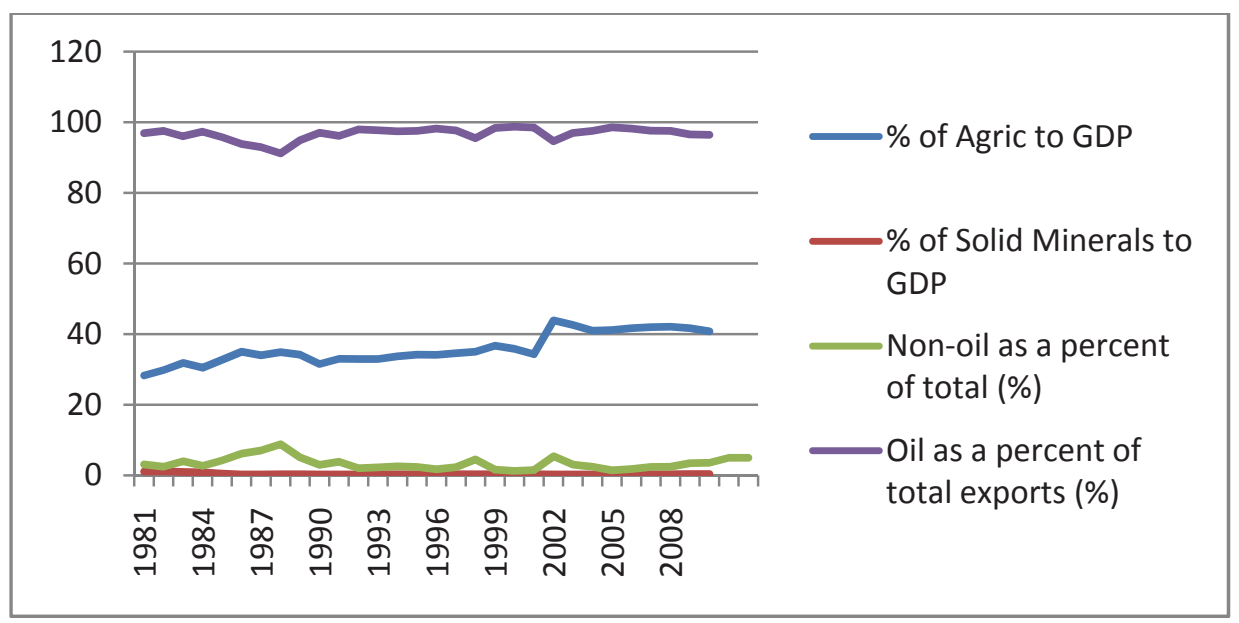

From table 2, we observe that although the agricultural sector of the economy contributes significantly to the GDP, the mining of solid minerals has always been low and this has hindered its capacity to enhance the GDP as well as the foreign exchange earnings. During the period under review, agricultural output contributed a maximum of $43.89 \%$ in 2002 and a minimum of $28.26 \%$ in 1981. On the whole, this sector has contributed significantly to the GDP, achieving an average of 35.90 during the period.

For the solid mineral sub-sector, the output has been insignificant with an average contribution of $0.38 \%$ during the period. The sub-sector attained a maximum contribution of $1.12 \%$ in 1982 and a minimum of $0.24 \%$ in 1986 . 
From the graph above, it can be observed that agricultural products are the dominant exports in the non-oil subsector. When the contributiion of the agricultural sector to the GDP rises, a rise in the non-oil exports is also noticed.

\section{DATA ANALYSIS}

If the model is specified as: GDP $=\beta_{0}+\beta_{1} N O X+\beta_{2} X R$, the result we would obtain is shown below in Table 4 .

Table 3 - Estimation Command

Estimation Command:

= = = = = = ニ = = = = = = = = = = =

LS RGDP C NOX XR

Estimation Equation:

$==$ = = = = = = = = = = = = = = = = =

$R G D P=C(1)+C(2)^{*} \mathrm{NOX}+\mathrm{C}(3)^{*} \mathrm{XR}$

Substituted Coefficients:

= = = = = = = = = = = = = = = = = = =

$R G D P=213930.452958+0.917129194752 * N O X+1785.88713528 * X R$

Table 4 - Regression result

Dependent Variable: RGDP

Method: Least Squares

Date: 12/12/12 Time: 22:42

Sample: 19812010

Included observations: 30

\begin{tabular}{lcccc}
\hline \hline Variable & Coefficient & Std. Error & t-Statistic & Prob. \\
\hline \hline C & 213930.5 & 7469.206 & 28.64166 & 0.0000 \\
NOX & 0.917129 & 0.094469 & 9.708206 & 0.0000 \\
XR & 1785.887 & 186.1095 & 9.595892 & 0.0000 \\
\hline \hline R-squared & 0.975661 & Mean dependent var & 359350.3 \\
Adjusted R-squared & 0.973858 & S.D. dependent var & 175803.2 \\
S.E. of regression & 28424.83 & Akaike info criterion & 23.44255 \\
Sum squared resid & $2.18 \mathrm{E}+10$ & Schwarz criterion & 23.58267 \\
Log likelihood & -348.6383 & Hannan-Quinn criter. & 23.48738 \\
F-statistic & 541.1588 & Durbin-Watson stat & 0.736569 \\
Prob(F-statistic) & 0.000000 & & \\
\hline
\end{tabular}

From the table above, we observe that the P-values of the parameters are significant. However, the DurbinWatson statistic reveals the presence of autocorrelation. We therefore seek a more suitable model for the study.

If the model is specified as: LOGRGDP $=\beta_{0}+\beta_{1} N O X+\beta_{2} X R$, we would obtain the following result. 
Table 5 - Estimation Command

Estimation Command:

= = = = = = = = = = = = = = =

LS LOG(RGDP) C NOX XR

Estimation Equation:

= = = = = = = = = = = = = = = = = = =

$\mathrm{LOG}(\mathrm{RGDP})=\mathrm{C}(1)+\mathrm{C}(2)^{\star} \mathrm{NOX}+\mathrm{C}(3)^{\star} \mathrm{XR}$

Substituted Coefficients:

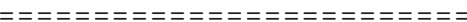

$\operatorname{LOG}(R G D P)=12.3000721366+1.27282250454 \mathrm{e}-06 * \mathrm{NOX}+0.00632839346218 * \mathrm{XR}$

Table 6 - Regression Result

Dependent Variable: LOG(RGDP)

Method: Least Squares

Date: 01/07/13 Time: 01:11

Sample: 19812010

Included observations: 30

\begin{tabular}{lllll}
\hline \hline Variable & Coefficient & Std. Error & t-Statistic & Prob. \\
\hline \hline C & & & & \\
NOX & 12.30007 & 0.028681 & 428.8606 & 0.0000 \\
XR & $1.27 \mathrm{E}-06$ & $3.63 \mathrm{E}-07$ & 3.508805 & 0.0016 \\
\hline \hline & 0.006328 & 0.000715 & 8.855391 & 0.0000 \\
R-squared & & & \\
Adjusted R-squared & 0.939435 & S.D. dependent var & & 12.69085 \\
S.E. of regression & 0.109148 & Akaike info criterion & & 0.443510 \\
Sum squared resid & 0.321657 & Schwarz criterion & & -1.497588 \\
Log likelihood & 25.46383 & Hannan-Quinn criter. & & -1.357469 \\
F-statistic & 225.9114 & Durbin-Watson stat & & -1.452763 \\
Prob(F-statistic) & 0.000000 & & & 0.608507 \\
\hline \hline
\end{tabular}

From the above result, the Durbin-Watson shows that there is autocorrelation

If the model is specified as: LOGGDP $=\beta_{0}+\beta_{1}$ LOGNOX $+\beta_{2} X R$, we would obtain the following result.

Table 7 - Estimation Command

Estimation Command:

$==$ = = = = = = = = = = = = = = =

LS RGDP C LOG(NOX) XR

Estimation Equation:

$==$ = = = = = = = = = = = = = = = =

RGDP $=\mathrm{C}(1)+\mathrm{C}(2)^{\star} \mathrm{LOG}(\mathrm{NOX})+\mathrm{C}(3)^{\star} \mathrm{XR}$

Substituted Coefficients:

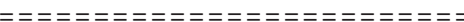

RGDP $=79746.4290391+16180.4972224 *$ LOG $(N O X)+2624.76545486 * X R$ 
Table 8 - Regression Result

Dependent Variable: RGDP

Method: Least Squares

Date: 01/07/13 Time: 01:12

Sample: 19812010

Included observations: 30

\begin{tabular}{lcccc}
\hline \hline Variable & Coefficient & Std. Error & t-Statistic & Prob. \\
\hline \hline C & 79746.43 & 72349.61 & 1.102237 & 0.2801 \\
LOG(NOX) & 16180.50 & 9669.922 & 1.673281 & 0.1058 \\
XR & 2624.765 & 445.4785 & 5.892013 & 0.0000 \\
\hline \hline R-squared & 0.900969 & Mean dependent var & 359350.3 \\
Adjusted R-squared & 0.893633 & S.D. dependent var & 175803.2 \\
S.E. of regression & 57336.37 & Akaike info criterion & 24.84590 \\
Sum squared resid & $8.88 \mathrm{E}+10$ & Schwarz criterion & 24.98602 \\
Log likelihood & -369.6885 & Hannan-Quinn criter. & 24.89072 \\
F-statistic & 122.8205 & Durbin-Watson stat & 0.406346 \\
Prob(F-statistic) & 0.000000 & & \\
\hline \hline
\end{tabular}

The above result is unsuitable because the P-values of the parameters are insignificant and there is negative autocorrelation.

If the model is specified as: LOGGDP $=\beta_{0}+\beta_{1} L O G N O X+\beta_{2} L O G X R$, we would obtain the following result.

Table 9 - Estimation Command

Estimation Command:

$==$ = = = = = = = = = = = = = = = = = =

LS LOG(RGDP) C LOG(NOX) XR

Estimation Equation:

$==$ = = = = = = = = = = = = = = = =

$\operatorname{LOG}(R G D P)=C(1)+C(2)^{*} \operatorname{LOG}(N O X)+C(3)^{*} X R$

Substituted Coefficients:

$==$ = = = = = = = = = = = = = = = =

$\operatorname{LOG}(R G D P)=11.6861108303+0.0808449074162 * \operatorname{LOG}(N O X)+0.00512224347246 * X R$

Table 10 - Regression result

Dependent Variable: LOG(RGDP)

Method: Least Squares

Date: 12/12/12 Time: 22:50

Sample: 19812010

Included observations: 30

\begin{tabular}{lcccc}
\hline \hline Variable & Coefficient & Std. Error & t-Statistic & Prob. \\
\hline \hline C & 11.68611 & 0.118607 & 98.52809 & 0.0000 \\
LOG(NOX) & 0.080845 & 0.015852 & 5.099833 & 0.0000 \\
XR & 0.005122 & 0.000730 & 7.013901 & 0.0000 \\
\hline \hline
\end{tabular}




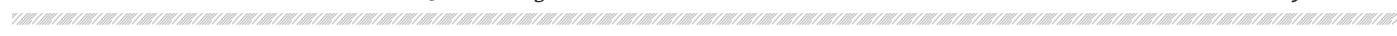

\begin{tabular}{llll} 
R-squared & 0.958182 & Mean dependent var & 12.69085 \\
Adjusted R-squared & 0.955084 & S.D. dependent var & 0.443510 \\
S.E. of regression & 0.093995 & Akaike info criterion & -1.796514 \\
Sum squared resid & 0.238546 & Schwarz criterion & -1.656395 \\
Log likelihood & 29.94772 & Hannan-Quinn criter. & -1.751689 \\
F-statistic & 309.3247 & Durbin-Watson stat & 0.645702 \\
Prob(F-statistic) & 0.000000 & & \\
\hline \hline
\end{tabular}

From the above table, we observe that the P-values of the parameters are also significant while the DurbinWatson statistic is also still unsuitable.

When the model is specified as: DLOGGDP $=\beta_{0}+\beta_{1}$ LOGNOX $+\beta_{2}$ LOGXR

to include lags in the dependent variable, we have;

Table 11 - Estimation command

Estimation Command:

$======================$

LS DLOG(RGDP) C LOG(NOX) XR LOG(RGDP(-1)) LOG(RGDP(-2))

Estimation Equation:

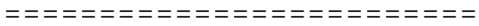

$\operatorname{DLOG}(R G D P)=C(1)+C(2)^{\star} \operatorname{LOG}(N O X)+C(3)^{\star} X R+C(4)^{\star} \operatorname{LOG}(\operatorname{RGDP}(-1))+\mathrm{HYC}(5)^{\star} \operatorname{LOG}(\operatorname{RGDP}(-2))$

Substituted Coefficients:

$==$ = = = = = = = = = = = = = =

DLOG(RGDP) $=2.15194937578+0.022338577613^{*}$ LOG(NOX) $+0.000905009670459 * X R+$ $0.139871363478 * \operatorname{LOG}(\operatorname{RGDP}(-1))-0.32761279204 * \operatorname{LOG}(\operatorname{RGDP}(-2))$

Table 12 - Regression result

Dependent Variable: DLOG(RGDP)

Method: Least Squares

Date: 12/08/12 Time: 17:18

Sample (adjusted): 19832010

Included observations: 28 after adjustments

\begin{tabular}{lllll}
\hline \hline Variable & Coefficient & Std. Error & t-Statistic & Prob. \\
\hline \hline C & 2.151949 & 0.960509 & 2.240426 & 0.0350 \\
LOG(NOX) & 0.022339 & 0.010487 & 2.130067 & 0.0441 \\
XR & 0.000905 & 0.000522 & 1.734681 & 0.0962 \\
LOG(RGDP(-1)) & 1.139871 & 0.191316 & 5.958048 & 0.0000 \\
LOG(RGDP(-2)) & -0.327613 & 0.179227 & -1.827923 & 0.0806 \\
\hline \hline & & & & \\
R-squared & 0.992377 & Mean dependent var & 12.72462 \\
Adjusted R-squared & 0.991052 & S.D. dependent var & 0.439915 \\
S.E. of regression & 0.041614 & Akaike info criterion & -3.360334 \\
Sum squared resid & 0.039829 & Schwarz criterion & -3.122440 \\
Log likelihood & 52.04467 & Hannan-Quinn criter. & -3.287607 \\
F-statistic & 748.5869 & Durbin-Watson stat & 1.998348 \\
Prob(F-statistic) & 0.000000 & & \\
\hline \hline
\end{tabular}


The table above shows that the P-value for the non-oil exports is significant while that of the real exchange rate is insignificant. Also, the Durbin-Watson statistic shows that there is no autocorrelation in the model.

From the regression result above, the constant or intercept is 2.151949 . This implies that when all the model parameters are zero, there will still be an effect of 2.151949 on the GDP. This is accounted for by other factors not specified in the model such as earnings from crude oil, earnings from the services sector, investments, etc.

The coefficient of non-oil exports, 0.022339 , shows that the earnings from exports of non-oil commmodities only has a minuscule effect of about $2.2 \%$ on the GDP of the nation. This shows that truly, the non-oil export sector has been performing at a level that is grossly inadequate and requires exploitation in order to reach its full potential.

The coefficient of the foreign exchange rate is 0.000905 . This shows that the real exchange rate has a negligible effect of $0.09 \%$ on the GDP. This is negligible and can be ignored as a factor affecting the exportation of non-oil commodities. The P-value is 0.0962 which is greater than 0.05 and is therefore insignificant.

The estimators $\operatorname{LRGDP}(-1)$ and $\operatorname{LRGDP}(-2)$ are included in the model in order (for EViews ${ }^{\mathrm{TM}}$ ) to perform a lagged analysis. From the analysis, they show that the GDP in one time period depends on the GDP in the two preceeding time periods.

The Adjusted $\mathrm{R}^{2}$ is 0.991052 . This shows that the independent variables specified in the model can explain only about $99 \%$ of the variations in the dependent variable.

The acceptable value for the Durbin Watson Statistic is 2 but it permits a range of \pm 0.2 . The DurbinWatson Statistic is 1.998348 and since it falls within the acceptable range, the model is free from autocorrelation and is reliable.

\section{Crosstabulations}

\begin{tabular}{c|c|c|c|}
\multicolumn{2}{c}{} & \multicolumn{3}{c}{ Correlation } \\
\hline & LRGDP & LNOX & XR \\
\hline LRGDP & 1.000000 & 0.939142 & 0.958071 \\
\hline LNOX & 0.939142 & 1.000000 & 0.881214 \\
\hline XR & 0.958071 & 0.881214 & 1.000000 \\
\hline \hline
\end{tabular}

From the table above, non-oil exports have an effect of about $94 \%$ on the real GDP and the foreign exchange rate also has an effect of about $94 \%$ on the real GDP. This is a very strong relationship as it tends towards $100 \%$. This is acceptable as it is between dependent and independent variables.

On the other hand, the strength of the association between the foreign exchange rate and the non-oil exports is about $88 \%$. This is not ideal because the two variables are independent variables. However, since the P-value of the foreign exchange rate shows that it is insignificant in this model, we can ignore this relationship.

\section{Test of hypothesis}

$\mathrm{H}_{\mathrm{o}}$ : That non-oil exports do not contribute significantly to Nigeria's Gross Domestic Product.

$\mathrm{H}_{1}$ : That non-oil exports contribute significantly to the nation's Gross Domestic Product.

To test this hypothesis, we will consider the value obtained from the estimation of the model with the table value. The P-value for non-oil exports is 0.0441 , which is less than 0.05 and is therefore significant. The $t-$ statistic for the non-oil exports obtained from the estimation is 2.130067 . The table value is 1.699127 at $5 \%$ level of significance. This implies that the contribution of non-oil exports receipts to the GDP is significant at the $5 \%$ level of significance. Therefore at the $5 \%$ level of significance, the alternate hypothesis is accepted while the null hypothesis is rejected.

Considering the t-statistic for the foreign exchange rate, we have 1.734681 and comparing this with what we have on the table which is 1.699127 , we observe that the table value is also less than the calculated value. This leads us reject the null hypothesis $\left(\mathrm{H}_{0}\right)$ and accept the alternate hypothesis $\left(\mathrm{H}_{1}\right)$. Conversely, this interpretation can be ignored because the $\mathrm{P}$-value of foreign exchange rate shows that it is insignificant in this model. 
For the F-Statistic, which apart from the Adjusted $\mathrm{R}^{2}$ also tells about the overall significance of the model, the value obtained through estimation is 0.000000 , while the table value is 748.5869 . Since the estimated value is greater than the table value, we reject the null hypothesis $\left(\mathrm{H}_{0}\right)$ and accept the alternate hypothesis $\left(\mathrm{H}_{1}\right)$ and the implication of this also is that the model is highly significant.

From the above results, it is clear that the earnings from the exports of non-oil commodities have been able to enhance the GDP of the nation. However, with an input of only about $2 \%$, the contribution of the non-oil export receipts can hardly be said to be significant. It will therefore be concluded that receipts from non-oil exports contribute to the GDP however, they do not contribute "significantly".

\section{Summary and conclusion}

This study has examined the type and strength of the relationship that exists between exports of non-oil commodities, focusing on agricultural and mineral resources. From the analysis, non-oil exports on the whole have performed below expectation thereby questioning the efficiency of the export promotion strategies and confirming the fact that the Nigerian economy is far from being diversified away from crude oil exports. This result is supported by Subasat (2002) which affirms that export promotion does not have any significant impact on the economic growth of low income countries. Also, the result confirms the findings of previous works done by Koester (1986) and Osuntogun et al(1997) on the role of export promotion in diversifying the productive base of African countries; they found out that regional trade encourages export diversification away from products traditionally exported to industrial countries. Nigeria concentrated export on developed countries such as USA and Europe, instead of expanding such to African regional markets in order to exploit the available potentials fully and diversify the productive base.

There are many factors contributing to the sub-optimal performance of non-oil exports in Nigeria as have been previously stated. However, the major ones include:

- Dearth of infrastructures which consequently raises the cost of production. A World Bank (1994) study established that such cost accounted for 15-20 percent of establishing industries in Nigeria.

- Lack of incentives to encourage non-oil exports. This could be financial or non-financial. Non-financial such as the tedious process involved in; documentation for exportation, obtaining loans and refunds under such policies as the duty drawback scheme.

- $\quad$ The protectionist policies of the developed countries which are usually in the form of tariffs which increase the sale price of the items and render them uncompetitive in such economies.

- Concentration of exports to developed countries instead of seeking out inter-regional markets which will encourage export diversification away from products traditionally exported to industrial countries.

- $\quad$ Lack of broad domestic supply base to service both domestic and foreign demand. This is particularly obvious in the case of mineral resources because there is very little investment in the subsector.

\section{Conclusion}

In conclusion, the result of this research has established that the performance of non-oil exports and their contribution to GDP is sub-optimal. From the problems highlighted, it is easy to see why the contribution of non-oil exports has remained insignificant. The various policies which were also implemented to correct this problem have failed to do so partly because the workability of such policies was not properly evaluated, partly because they were not strictly implemented and partly for other reasons. In order to increase the revenue that accrues to the economy through the exports of non-oil commodities, the government should put in place those policies that will enhance the productivity of the individual sectors and subsectors of the economy and that will encourage the exportation of non-oil commodities. It is expected that if the government and other economic agents implement these recommendations and take them into consideration when formulating policies, the economic prosperity of Nigeria will commence.

\section{Recommendations}

This study has brought to light certain lapses and factors that have hindered the profitablity of the non-oil 
export sector. In light of these challenges, the following recommendations are suggested:

1. Formulation of an explicit export promotion programme based on principles of comparative advantage or disadvantage

2. Reducing trade dependence on developed countries by looking for other markets, particularly developing countries. Inter-regional trade between Sub-Saharan African countries should also be encouraged because of the relatively low transportation cost and lax importation barriers.

3. The government should encourage private investment, both local and foreign, through adequate provision of infrastructures.

4. The export base should be diversified in favour of non-oil commodities not only to increase their contribution to GDP but also to help cushion the effect of price shocks in the international oil (crude oil) market.

5. Oil explorers, producers and exporters should be persuaded to diversify their interests into non-oil commodities as well or they could be obligated to somehow assist with the exports of non-oil commodities.

6. Promotion of a stable political and macroeconomic environment that encourage exportation, particularly of non-oil commodities.

7. Encouragement of production and exportation of value added commodities because of its relatively high price and income elasticises of demand, storability and adaptability over primary products such as processed agricultural products or foods.

8. Incentives attached to non-oil exports should be continually reviewed and improved as well as strictly implemented.

9. Direct government intervention through minerals exploration.

If the various recommendations are properly implemented, then the contribution of non-oil exports to GDP is expected to increase to a significant level. It will also help absorb any shocks from the international oil market and Nigeria will be on its way to economic prosperity.

\section{References}

Abayomi, Y. O. (1997, July/September). The Agriculural Sector in Nigeria: The Way Forward. Bullion, 21(3).

Abebefe, H. A. (1995, October/December). The Structure of Nigria's External Trade. Bullion, 19(4).

Abou-Strait, F. (2005, July). Are Exports The Engine Of Economic Growth? An Application of Cointegration and Causality Analysis for Egypt, 1977-2003. African Development Bank, Economic Research Working Paper.

Carbaugh, R. (2004). International Economics (10 ed.). Ohio: Thomson.

CBN, D. R. (2010). The Changing Structure of the Nigerian Economy (2nd ed.). (C. N. Mordi, A. Englama, \& B. S. Adebusuyi, Eds.) Ikeja, Lagos: Atisele Vanessa Cards Co. Retrieved August 30, 2012

Daisi, K. (2001, July/Sept.). Non Oil Export Promotion: Concepts, Issues and Prospects. CBN Bullion, 25(3), 32-38. Retrieved August 23, 2012

Dakare, R. M. (n.d.). Export promotion and economic growth: The Nigerian Experience. pp. 80-91.

Dunn, R. M., \& Mutti, J. H. (2004). Trade and growth. In International Economics (6th ed., pp. 221-241). London: Routledge.

Frankel, J. A., \& Romer, D. (1999, June). Does Trade Cause Growth? The American Economic Review, 89(3), $379-399$. Retrieved August 7, 2012, from http://www.jstor.org/stable/117025

Gairuzazmi, G. (2006). Export Promotion Policies and the Crowdhing out Effect on Developing Countries. Asian Economic Journal, 20(3), 319-331.

Hoag, A. J., \& Hoag, J. H. (2006). Trade Without Money. In A. J. Hoag, \& J. H. Hoag, Introductory Economics (4 ed., p. 520). Singapore, Singapore: World Scientific Publishing Co. Pte. Ltd.

Koester, U. (1986). Regional Cooperation to Improve Food Security in Southern and Eastern African Countries. Research Report 53, International Food policy Research Institute, Washington D.C.

Lewis, W. (1980). The Slowing Down of Engine or the Engine of Growth. American Economic Review, 70(4).

Lyakurwa, W. M. (1991). Trade Policy and Promotion in sub-Saharan Africa. Africa Economic Research Consortium(Special Paper 12).

Madaki, R. O. (2001, July/September). Institutional and Other Constraints to Non-Oil Exports. Bullion, 25(3).

Morton, K., \& Tullock. (1976). Trade and Developing countries. London: Groom Aelen Itd.

Odularu, G. O. (2008). Crude Oil and The Nigerian Economic Performance. Oil and Gas business, 1-29. 
Ogunkola, E. O., Bankole, A. S., \& Adewuyi, A. O. (2006, March). An Evaluation of the Impact of Nigeria's Trade and Investment Policy Reforms. University of Ibadan, Department of Economics. Nairobi, Kenya: African Economic Research Consortium (AERC). Retrieved August 21, 2012

Opara, B. C. (2010, March). Export Marketing: Catalyst for Nigeria Economic. Research Journal of Internatıonal Studies(13).

Osuntogun, A., Edordu, C. C., \& Oramah, B. O. (1997, November). Potentials for diversifying Nigeria's non-oil exports to non-traditional markets. AERC Research Paper, No. 68.

Oti, J. C. (1992). Diversification Of Exports In Nigeria: A Comparative Ratio Analysis of Performance Under Regulated and De-Regulated Economy. University of Nigeria, Nsukka, Department of Banking and Finance. Enugu: University Llibrary.

Salvatore, D., \& Diulio, E. A. (2003). Principles of Economics. Schaum's Easy Outlines, McGraw Hill.

Schumpeter, J. A. (1934). The Theory of Economic Development. Cambridge, MA: Harvard University Press.

Singh, T. (2010). Does International Trade Cause Economic Growth? A Survey. The World Economy, 1554. doi:10.1111/j.1467-9701.2010.01243.x

Smith, A. (1776). An Inquiry into the Nature And Causes Of Wealth Of Nations. New York: Random House, 1937.

Subasat, T. (2002). Does Export Promotion Increase Economic Growth? Some Cross-Sector Evidence. Economic Policy Review, 2, 315-349.

Sylvester, J., \& Aiyelabola, O. O. (2012, August). Foreign Trade and Economic Growth: Evidence From Nigeria. Arabian Journal of Business and Management Review (OMAN Chapter), 2(1).

Todaro, M. (1996). Economic Development. USA: Black Star Publishing company.

Todaro, M. P., \& Smith, S. C. (2011). Economic Development (11th ed.). USA: Addison Wesley.

World Bank. (1994). World Development Indicators.

World Trade Organisation. (2010). 10 benefits of the WTO trading system. 